$2-2004$

\title{
Collapse of 2000 Commonwealth Avenue: Punching Shear Case Study
}

Suzanne King

Roger Williams University

Norbert Delatte

Cleveland State University, n.delatte@csuohio.edu

Follow this and additional works at: https://engagedscholarship.csuohio.edu/encee_facpub

Part of the Civil Engineering Commons, and the Structural Engineering Commons

How does access to this work benefit you? Let us know!

\section{Publisher's Statement}

(C) ASCE

\section{Original Citation}

King, S., and Delatte, N. (2004). "Collapse of 2000 Commonwealth Avenue: Punching Shear Case Study." J.Perform.Constr.Facil., 18(1), 54-61.

This Article is brought to you for free and open access by the Civil and Environmental Engineering at EngagedScholarship@CSU. It has been accepted for inclusion in Civil and Environmental Engineering Faculty Publications by an authorized administrator of EngagedScholarship@CSU. For more information, please contact library.es@csuohio.edu. 


\title{
Collapse of 2000 Commonwealth Avenue: Punching Shear Case Study
}

\author{
Suzanne King, S.M.ASCE, ${ }^{1}$ and Norbert J. Delatte, M.ASCE ${ }^{2}$
}

\begin{abstract}
On January 25, 1971, two thirds of a 16-story apartment building collapsed while under construction at 2000 Commonwealth Avenue, Boston, Massachusetts. Four workers died after a failure on the roof instigated a progressive collapse all the way to the basement, where the men were found. Fortunately, the collapse occurred slowly enough for most of the other workers to run to safety. An investigation, conducted by a commission assembled by the Mayor of Boston, painted a picture of a troubled project, with considerable confusion about responsibility for structural safety. The surviving workers' descriptions of the failure provide a textbook definition of punching shear. Low concrete strength due to inadequate protection against cold weather contributed to low punching shear strength of the flat slab. Inspection, quality control, planning, and supervision were for all practical purposes absent from the project. This paper investigates the numerous causes and lessons learned of this structural failure. Two similar cases are also reviewed.
\end{abstract}

CE Database subject headings: Collapse; Buildings, residential; Massachusetts; Boston; Structural failure; Case reports.

\section{Introduction}

Four workers died when about two-thirds of a 16-story apartment building under construction collapsed on January 25, 1971. The next day's Boston Globe newspaper featured dramatic photographs of the remains of the collapsed structure. Two of the photographs accompanying the article are shown as Figs. 1 and 2. Rescue operations were delayed because of concerns about the stability of the remaining structure (Blake 1971). Nearly 71.6 MN $(8,000 \mathrm{t})$ of debris were removed before the bodies of the workers could be recovered (Granger et al. 1971). A building that had been in development for over 6 years collapsed in a few minutes. Fortunately, the collapse occurred slowly enough that most of the men working on the site were able to escape.

Punching shear was believed to have triggered the collapse. An investigation called for by the mayor found that there had been many errors and omissions associated with the apartment building. Over the long period of development, there had been many changes in the building's owners and designers, leading to considerable confusion (Granger et al. 1971). Some of the key events are listed in Table 1. It is difficult to trace the project ownership and to determine who was responsible for the safety and structural integrity of the project.

\section{Design and Construction}

The building was a cast-in-place reinforced concrete flat slab construction with a central elevator shaft core. This style of construc-

\footnotetext{
${ }^{1}$ Formerly, Student, Roger Williams Univ. School of Engineering, One Old Ferry Rd., Bristol, RI 02809.

${ }^{2}$ Associate, Professor, Dept. of Civil and Environmental Engineering, Cleveland State Univ., Cleveland, OH 44115.
}

tion is popular for multistory buildings because it reduces the slab thickness and the overall height of the building (Feld and Carper 1997). The flat slabs were $190 \mathrm{~mm}$ (7 1/2 in.) thick, except for some bays near the elevator core and at stairwells, which were $230 \mathrm{~mm}$ (9 in.) thick. This made possible a story height of $2.7 \mathrm{~m}$ $(9 \mathrm{ft})$ for most of the floors.

The building at 2000 Commonwealth Avenue was designed to be 16 stories high with a mechanical room above a $1.5-\mathrm{m}(5-\mathrm{ft})$ crawl space on the roof. The building was 55.1 by $20.9 \mathrm{~m}(180 \mathrm{ft}$ 10 in. by $68 \mathrm{ft} 6$ in.) in plan. The floor plan is shown in Fig. 3. The structure also had two levels of underground parking. A swimming pool, ancillary spaces, and one apartment were located on the first floor and 132 apartments were on the second through sixteenth floors. Originally these apartments were to be rented, but the owners later decided to market them as condominiums (Granger et al. 1971).

Construction began on the site late in the fall of 1969. Nearly all of the work was subcontracted. Only one representative from the general contractor was on site during construction.

At the time of collapse, construction was nearing completion. Brickwork was completed up to the sixteenth floor and the building was mostly enclosed from the second to fifteenth floors. Plumbing, heating, and ventilating systems were being installed throughout various parts of the building. Work on interior apartment walls had also started on the lower floors. A temporary construction elevator was located at the south edge of the building to aid in transporting equipment to the different floors. It is estimated that 100 men were working in or around the building at the time of failure (Granger et al. 1971).

\section{Collapse}

After interviewing many eyewitnesses, the mayor's investigating commission concluded that the failure took place in three phases. These phases were (1) punching shear failure in the main roof at column E5; (2) collapse of the roof slab; and (3) the progressive and general collapse of most of the structure (Granger et al. 1971). 


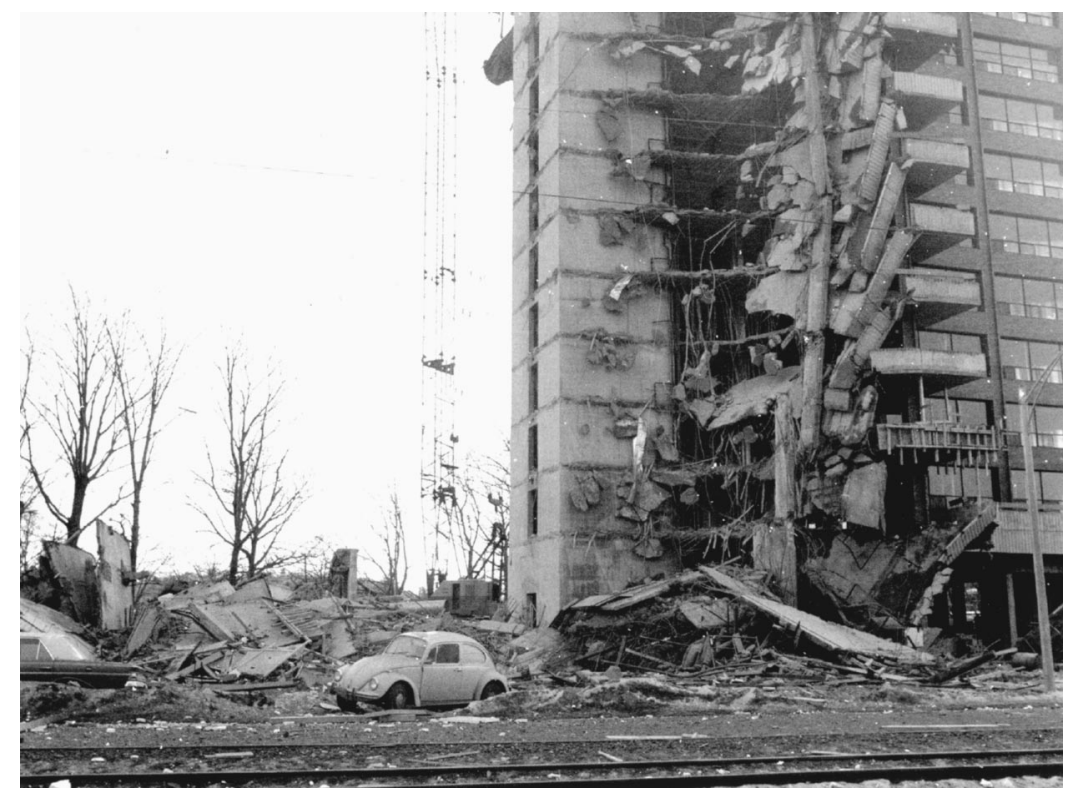

Fig. 1. Chunks of concrete and wood were strewn across MBTA track (in foreground) by building collapse [from Boston Globe, January 26, 1971; republished with permission]

\section{Phase 1: Punching Shear Failure in the Main Roof at Column E5}

At about 10 in the morning on the 25 th of January, 1971, concrete was being placed in the mechanical room floor slab, wall, wall beams, and brackets. Placement started at the west edge and proceeded east. Later in the afternoon, at about 3 o'clock, most of the workers went down to the south side roof for a coffee break. Only two concrete finishers, Mr. D. N. and Mr. J. O., remained on the pouring level.

Shortly after the coffee break, the two men felt a drop in the mechanical room floor of about $25 \mathrm{~mm}$ (1 in.) at first and then another $50-75 \mathrm{~mm}$ ( 2 or 3 in.) a few seconds later. The labor foreman, Mr. A. P., was directing the crane carrying the next bucket of concrete. He instructed the operator to "hold the bucket" and went down to the sixteenth floor by way of a ladder in the east stairway. That is when he noticed the punching shear around column E5. He stated: "I can't believe my eyes. I see this slab coming down around the column." (Granger et al. 1971, p. 13).

The carpenter foreman, Mr. A. F., was also in the area and immediately yelled a warning to the men working on the sixteenth floor and roof of a possible roof collapse. The slab had dropped $125-150 \mathrm{~mm}$ ( 5 or 6 in.) around the column, and there was a crack in the bottom of the slab extending from column E5 toward column D8. Column E5 is located directly below where the concrete was being placed for the mechanical room floor slab on the east side of the building, as shown in Fig. 3 (Granger et al. 1971).

\section{Phase 2: Collapse of the Roof Slab}

After hearing Mr. A. F.'s warning, most of the workers in the area of column E5 managed to run to an east balcony and stay there until after the roof slab collapse. Eyewitness testimony concluded that the collapse happened fairly quickly. The roof slab began to sag in the shape of a belly and reinforcing steel began popping out from the mechanical room floor slab. The structure started to shake and the east half of the roof slab collapsed onto the sixteenth floor. Then it stopped, giving the workers a chance to run down the stairs to the ground.

At the time of failure, the structural subcontractor was placing reinforcing steel for the stairs on the fourteenth and fifteenth floors on the east side of the building. When the workers were making their way from the roof and floors above, most of them crossed over to the west side of the building when they reached the fifteenth floor (Granger et al. 1971). Thus, the portion of the building that remained standing, shown on the right side of Fig. 1, provided an escape for many of the workers that survived.

\section{Phase 3: General Collapse}

After the roof collapsed, the roof settled and most of the stranded workers could be rescued using the crane and construction elevator. However, about 10-20 min after the roof failed, the east side of the structure began to collapse. A resident of 1959 Commonwealth Avenue described the collapse as a domino effect (or progressive collapse). The weight of the collapsed roof caused the sixteenth floor to collapse onto the fifteenth floor, which then collapsed on the fourteenth floor, and so on to the ground (Litle 1972).

At first the different floors were distinguishable, but later dust and debris made it difficult to tell them apart. When the dust finally settled, two-thirds of the building had collapsed. The east side and areas on either side of the elevator shaft were gone. Four workers were killed during the collapse, and 30 workers suffered injuries (Granger et al. 1971). The extent of damage is shown in Fig. 4. The elevator core probably prevented the collapse from propagating to the other half of the structure.

\section{Commission Investigation}

A commission of inquiry was selected by the mayor of Boston and convened a week after the collapse. The Associated General Contractors of Massachusetts, the Boston Society of Architects, 


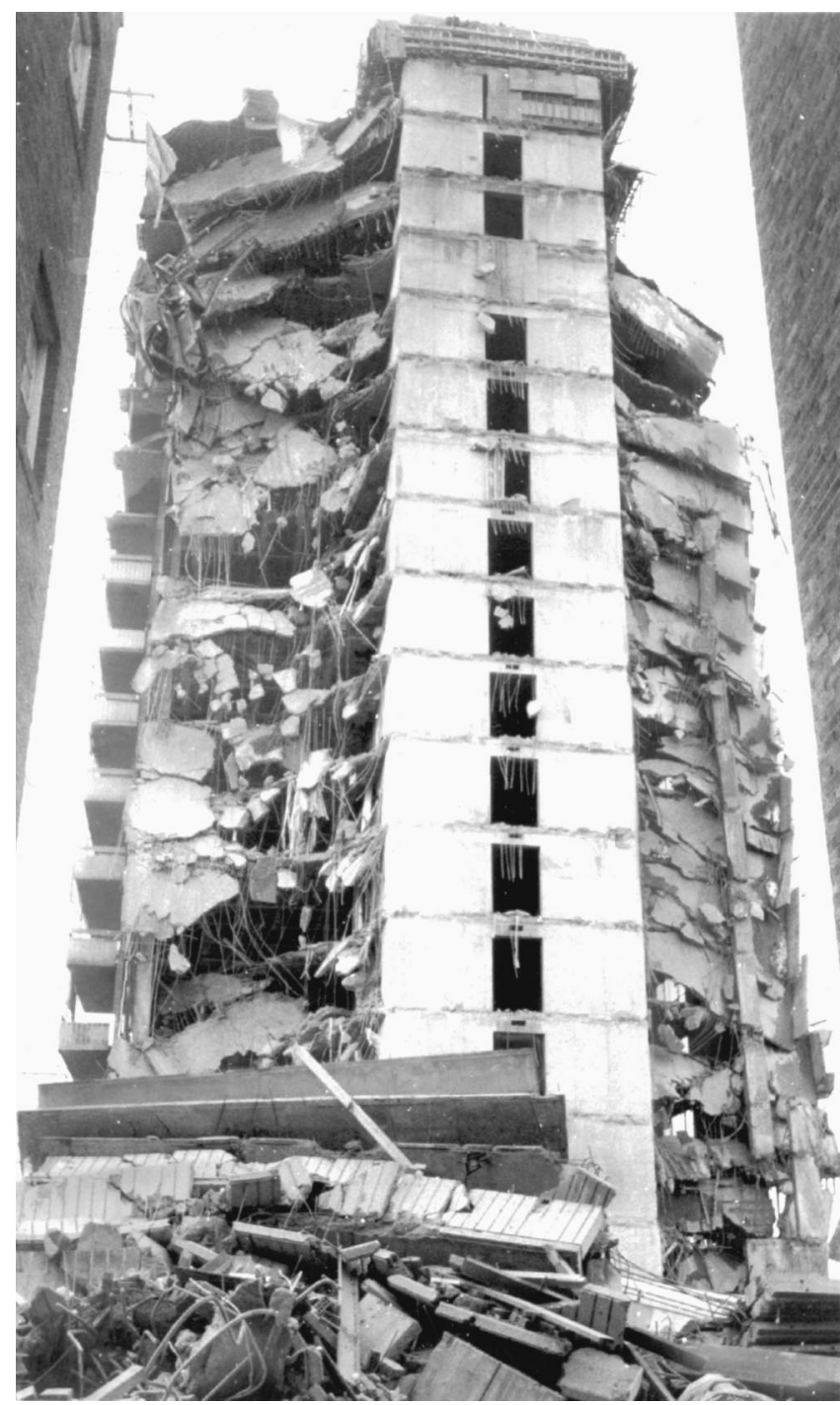

Fig. 2. Building collapse; four men missing and three injured when apartment under construction collapsed in Brighton [from Boston Globe, January 26, 1971; republished with permission]

the Boston Society of Civil Engineers, and the Boston Building and Construction Trades Council had representatives on the commission. Professor William A. Litle of the Massachusetts Institute of Technology helped draft the commission report and later reported on the failure (Litle 1972).

The commission retained an engineering firm and a testing laboratory to aid in the investigation. The commission interviewed a number of eyewitnesses, but suspended the interviews after about a dozen because there was no significant disagreement between the accounts (Granger et al. 1971).

The commission made a number of important findings:

- There were a number of irregularities in the issuance of the building permit. Key drawings were missing. Not a single drawing found in the file carried an architect's or engineer's registration stamp. The structural engineer refused to provide the calculations supporting his design to the commission. No principal or employee of the general contractor held a Boston builder's license. At the time, partial drawings could be used to obtain a building permit, with the understanding that final stamped drawings would have to be supplied before construction could begin.
- Ownership of the project changed a number of times, with changes in architects and engineers. This added to the overall confusion and contributed to the irregularities cited previously. Some of the key changes are outlined in Table 1.

- The general contractor only had a single employee on site, and most subcontracts were issued directly by the owner to the subcontractors and bypassed the general contractor. At least seven subcontractors were involved.

- The structural concrete subcontract did not require any inspection or cold weather protection of the work, although the designer had specified these measures. There was no evidence of any inspection of the work by an architect or engineer, although the project specifications required this.

- The concrete mix designs were not prequalified. Such prequalification was a Boston Building Code requirement and stipulated that the performance of the proposed concrete be verified by laboratory testing. Some concrete deliveries did not contain the required air entrainment. Calcium chloride was used as an accelerator for some of the concrete, although it was specifically prohibited by the designer's specifications. The designer's specifications included a water-reducing admixture, which was used in only a small percentage of the concrete supplied. The Boston Building Code requirements for inspection and testing were not met on $65 \%$ of the days concrete was delivered to the project. Chemical analyses also suggested that some samples had low cement content.

- The triggering mechanism of the collapse was punching shear at the roof slab around column E5, probably preceded by flexural yielding of the roof slab adjacent to the east face of the elevator core.

The commission examined the failure from three aspects:

- Whether failure would have been expected if the construction had conformed to the design documents;

- Whether the construction procedures and materials conformed to the design documents; and

- Whether the design documents met the building code requirements.

The commission concluded that the failure would not have occurred if the construction had conformed to design documents, and that the construction procedures and materials were deficient. The most significant deficiencies were a lack of shoring under the roof slab and low strength concrete. The design documents specified a 28-day strength of $20 \mathrm{MPa}(3,000 \mathrm{psi})$. At the time of the failure, 47 days after casting, the concrete had yet to achieve the 28-day strength.

There was some confusion as to whether the concrete at the point of the collapse had been cast on December 3 or 9, 1970. Both concrete placements had deficient strength, with 11 and 13 $\mathrm{MPa}(1,600$ and 1,900 psi) at 47 and 53 days, respectively. The commission believed that these two factors, lack of shoring and low concrete strength, were the principal cause of the collapse.

However, the commission also found that the design did not meet code requirements for the slab thickness at column E5. The minimum thickness requirement was governed by deflection and not by strength, but a thicker slab would have provided a greater safety margin against punching shear (Granger et al. 1971).

Although the structural plans limited construction loading to $1.44 \mathrm{kPa}(30 \mathrm{psf})$, actual loads were estimated to approach 6.22 $\mathrm{kPa}(130 \mathrm{psf})$. Some boilers and construction equipment were stored on the roof at the location where the failure began. The locations of shores were specified on the structural plans, but these requirements were ignored (Granger et al. 1971). Witnesses reported that there were few shores. 
Table 1. Event Table for Construction of 2000 Commonwealth Avenue Apartment Building

Date Action

November 3, 1964

First building permit application was filed for a seven-story, 89 apartment building. B.C. is listed as owner and S. E. is listed as architect. Permit was first refused because building exceeded allowable building height. A later appeal granted the permit on December 24, 1964.

May 24, 1965

Letter filed by W. L. of La Mont Corporation stated that construction of the building had started. Records show excavation was started and the lot was fenced.

August 16, 1967

Notice was given to B. C. by the building department that his permit had lapsed due to unreasonable delay in completing the building.

November 20, 1967 B. C. filed a new building permit for a 14-story, 85 apartment luxury building, naming G. G. architect.

However, the permit was not signed by "the person who is to perform or take charge of the work covered by the permit" as specified by codes. Therefore, the permit was not issued. The application was then deemed abandoned because there was no permit issued within 6 months of application.

July 3, 1968

A zoning change for the property was obtained by H. K.

December 23, 1968

W. F. of Toronto, Canada; M. F. and T. H., both of Montreal, Canada; and A. H., B. C., H. K., S. R., and L. P., all of Massachusetts, are named owners of the property at 2000 Commonwealth Avenue.

July 7, 1969 A permit was issued for a 16-story reinforced-concrete building designed by the architectural firm of W, Z, and M of West Toronto, Canada. However, Massachusetts state laws require permits to bear the seal of a registered architect or registered professional engineer from Massachusetts and the architectural firm of W, Z, and M does not have any principal or employees in Massachusetts.

August 1, 1969

August 27, 1969

An excavation permit is issued to B. C. as the authorized agent for the owner and T. Construction Co. as contractor. Another building permit is applied for, this time naming J. P. as owner or authorized agent and T. Construction, Inc., as contractor. Also, the signature of D. M. of Cochituate, Mass., appeared in the space for the signature of a licensed builder. It is later revealed that D. M. was not a licensed builder at the time.

August 29, 1969 A sworn affidavit states that the structural plans, drawn by M. S. Y. and Associates, were in accordance with the Building Codes of the City of Boston.

September 4, 1969

There is a change of ownership. Two of the previous owners drop out and three more join the existing owners, called the 2000 Commonwealth Associates.

September 5, 1969 The building permit is granted. However, the mayor's commission's report describes many irregularities and discrepancies-with this permit.

Fall 1969

Fall 1969 to 1970

Construction begins on 16-story apartment building.

November 10, 1970

but no units are sold.

Ownership changes yet again. This time M. A., B. C., and L. W. are made trustees of the 2000 Commonwealth

Association Trust.

January 25, 1971

Building collapses.

The commission also noted a number of deficiencies and deviations with reinforcement placement. These included (Granger et al. 1971):

- Omission of column ties in the bottom $1 \mathrm{~m}$ (39 in.) or so of several columns;

- Concrete cover for vertical column bars varying between 13 and $200 \mathrm{~mm}(1 / 2$ and 8 in.) instead of the specified $48 \mathrm{~mm}(1$ $7 / 8$ in.).

- One collapsed column had only six instead of eight $19 \mathrm{~mm}$ (3/4 in., U.S. \#6) longitudinal reinforcing bars, with similar discrepancies in other columns.

- East-west top slab steel was specified to be four $40.8 \mathrm{~mm}$ bars

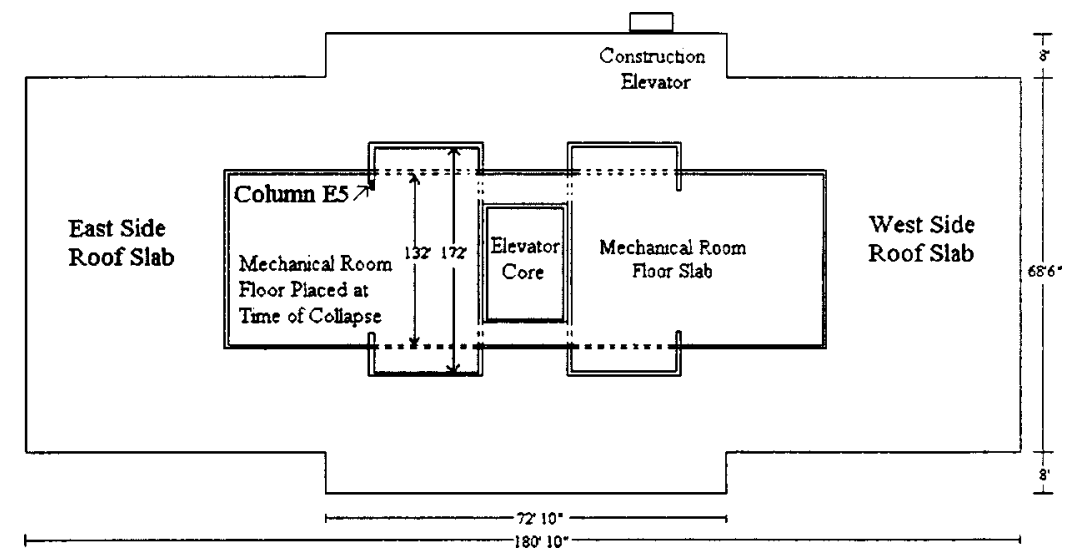

Fig. 3. Floor plan and location of column $E 5$ [after Granger et al. (1971)] (1 ft=0.3 m) 


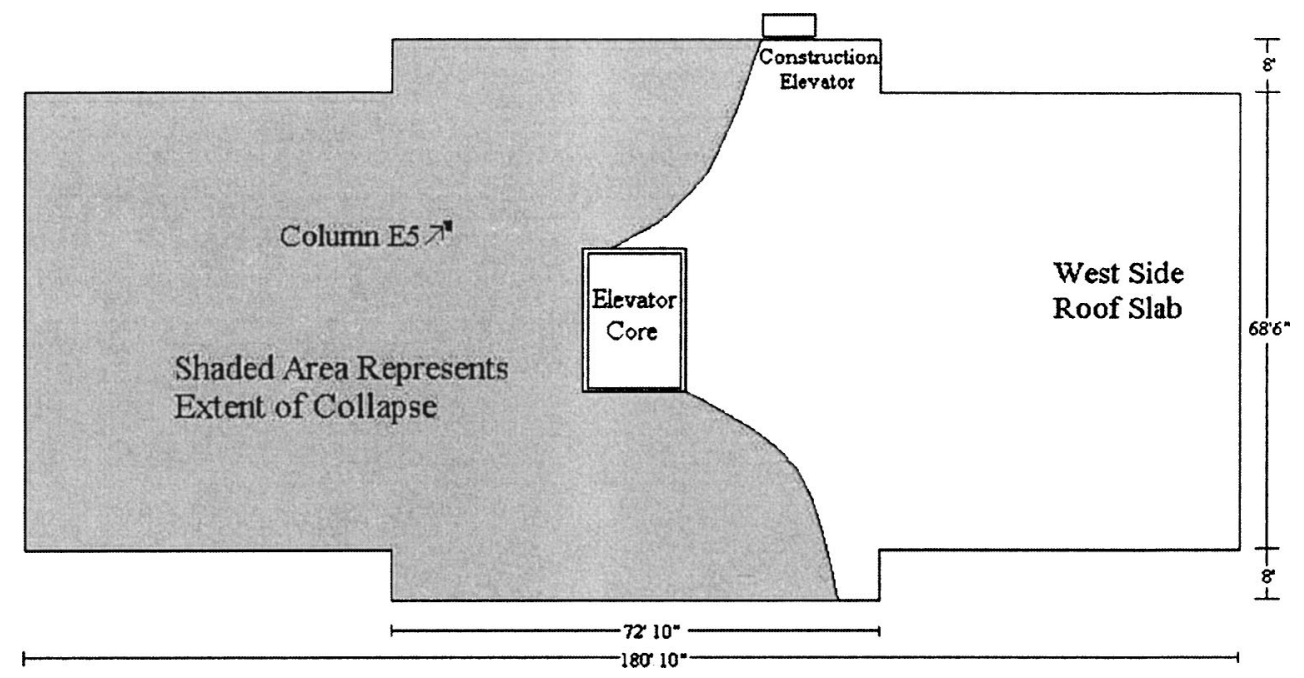

Fig. 4. Extent of collapse [after Granger et al. $(1971)](1 \mathrm{ft}=0.3 \mathrm{~m})$

(3/4 in., U.S. \#6) and five $13 \mathrm{~mm}$ (1/2 in., U.S. \#4). None of the larger bars were found, and the smaller bars were used consistently in place of the larger bars.

- The vertical position of the slab reinforcement was erratic. In some cases, the top steel was at or below the middepth of the slab.

- The collapse occurred near a construction joint, and the structural plans specified additional steel dowels across such joints. The witness testimony indicated that these dowels were not placed.

\section{Punching Shear Mechanism}

Punching shear is usually the critical failure mechanism for flat slab reinforced concrete structures. This mechanism is illustrated in Fig. 5. With this type of failure, the column and part of the slab punch through the slab as it moves downward.

The force acting on the slab around a column overcomes the resistance and the slab falls down around the column. A portion of the slab is left around the column, but the remainder of the slab falls to the next floor. If the lower slab is unable to hold up both floors, then a progressive collapse will begin.

Also, punching shear redistributes forces acting on the failed slab to other columns. If the other columns cannot carry the added weight, then the slab will start punching through the surrounding columns as well. Punching shear at one column can initiate a complete failure of a building.

The punching shear strength of a flat slab (without shear reinforcement) depends on five factors (Ghosh et al. 1995):

1. Concrete strength,

2. Relationship of size of loaded area to slab thickness,

3. Shape of loaded area,

4. Shape of perimeter area, and

5. Ratio of shear force to moment at slab-column connection.

The punching shear strength $V_{c}$ of a flat slab, for a simplified case of an interior column, may be expressed in U.S. customary units as (Ghosh et al. 1995):

$$
V_{c}=4 \sqrt{f_{c}^{\prime}} b_{0} d
$$

where $f_{c}^{\prime}=28$-day cylinder compressive strength of the concrete; $d=$ depth of the slab (measured from the bottom of the slab to the reinforcing steel location); and $b_{0}=$ perimeter of the failure surface around the column measured at distance $d$ from the face of the column. For SI units the constant, 4, changes, but the relationships between the variables remain the same.

Therefore, the punching shear strength of a flat slab depends on concrete strength and slab depth. Punching shear strength varies as the square root of the concrete strength. The effect of slab
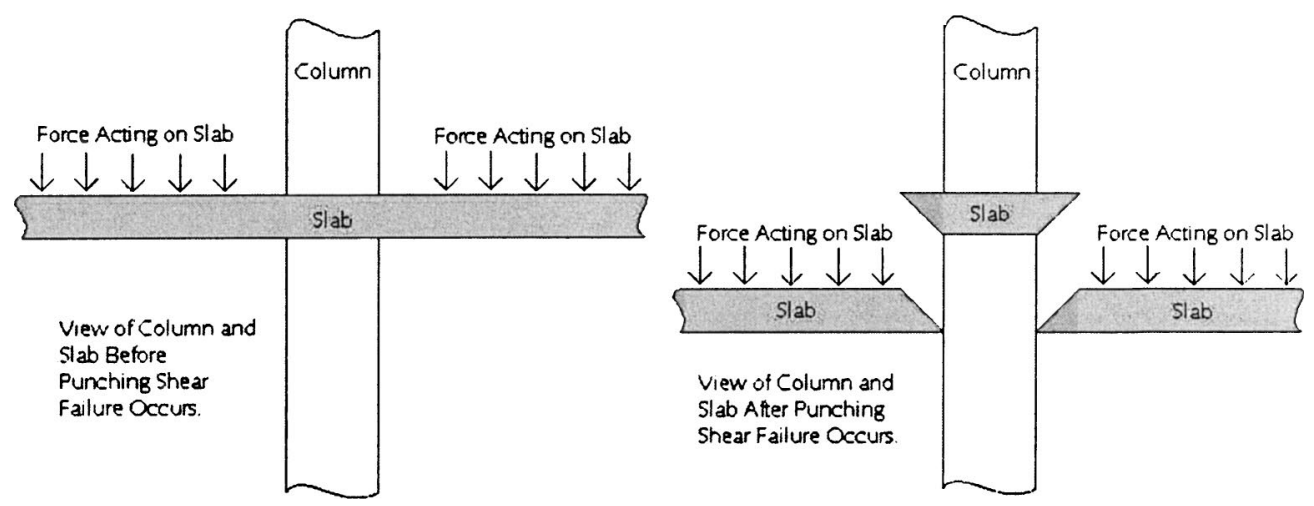

Fig. 5. Punching shear mechanism 
thickness is more than linear, because increasing $d$ also increases $b_{0}$ slightly. The lower concrete test strengths cited previously would lead to a punching shear capacity reduction of $20-27 \%$. The low placement of top steel bars in the slabs would lead to an even greater reduction of punching shear capacity.

\section{Review of Causes of Failure}

A week after the collapse, Engineering News Record reported that there were three possible causes of structural failure under investigation: (1) formwork for the penthouse floor slab collapsing onto the roof; (2) a heavy piece of equipment falling from a crane and starting the progressive collapse; or (3) failure of weak concrete placed during previous cold days ("Cause" 1971). After an extensive investigation, the mayor's commission concluded that there were many flaws that contributed to the collapse.

The committee determined that punching shear failure at column E5 triggered the initial collapse. The major areas of construction that did not follow the design were shoring and concrete strength. Inadequate shoring under the roof slab on the east side of the building made it impossible for the roof to hold the freshly placed concrete for the mechanical room floor slab, the construction equipment, and the two boilers that were stored on that side of the building. Also, the concrete strength of the roof slab was well below the $20 \mathrm{MPa}$ (3,000 psi) specified in the design (Granger et al. 1971).

Deficient concrete strength could be attributed to poor quality concrete, improper curing, or both. Tests indicated that the amount of cement in the concrete was sufficient, but records suggested that the maximum permissible slumps were consistently exceeded. The slump specification was only met in 37 of 240 tests. This could indicate too much water, leading to lower strength concrete.

Also, testimony indicated that the specifications for concrete protection in cold weather were not followed. Average curing temperature from the day of placement until the day of collapse was $-4^{\circ} \mathrm{C}\left(25^{\circ} \mathrm{F}\right)$. The concrete was not protected against the effects of cold weather. The commission believed that poor curing seriously retarded concrete strength gain (Granger et al. 1971).

The commission also found that the reinforcing steel details did not provide for sufficient steel crossing columns or for sufficient development length. One important detailing error was that the bottom slab bars were not long enough to tie into the core walls. Furthermore, significant differences were found between the structural drawings and the location and amount of steel in the parts of the building that were recovered. In some locations, as little as one-half of the specified top slab steel was actually placed. There were no ties in column splice regions. Although these errors did not contribute to the initiation of the collapse, they probably influenced the speed and extent of the propagation of the failure (Granger et al. 1971).

\section{Design and Detailing Concerns}

The design and detailing concerns that contributed to the collapse include insufficient length and placement of rebar and various structural design deficiencies. The steel was delivered by the supplier in bundles with marks on the steel indicating the intended use and location in the structure. However, some of the marks used were the same as the marks on the design plans, yet had a different meaning.
For example, the supplier gave marks for bars at the south edge of the slab that were identical to marks given on the engineer's drawings for top slab bars over column E5. The commission was unable to determine what procedures were used to actually select and place the reinforcement, and how confusion in the field with regard to the bar markings may have contributed to the collapse (Granger et al. 1971).

There were also detailing errors in the reinforcement. Some of the bars were not long enough to provide adequate development into the columns and walls as required by code, and placement of bars in some of the slabs was not sufficient to meet the American Concrete Institute's (ACI) code at the time. ACI required that at least $25 \%$ of the negative slab reinforcement in each column strip pass over the column within a distance of " $d$ " on either side of the column face (Granger et al. 1971). This requirement was not fulfilled.

The Commission found that the slab should have been 222 mm (8 3/4 in.) thick to satisfy the ACI 318-63 (ACI 1963) code requirements. However, this limit is based on deflection, and not on strength (Granger et al. 1971). It should be emphasized that there were no indications of inadequate design. Rather, the builders failed to adhere to the plans and specifications, and the owner failed to provide for proper inspection of the work.

\section{Procedural Concerns}

There were many procedural concerns in the construction of 2000 Commonwealth Avenue. For all practical purposes, there was no supervision of the construction. Nearly every step of construction was flawed (Kaminetzky 1991). Some of the major concerns include lack of proper building permit and field inspection, premature removal of formwork, and lack of construction control.

The investigating committee determined that if the construction had had a proper building permit and had followed codes then the failure could have been avoided. Since there were numerous problems that all played a part in the collapse, deciding whom to hold responsible for the collapse became difficult. Ownership changed hands many times, and most jobs were subcontracted. Some of the transactions that took place with Boston's Building Department are listed in Table 1 (Granger et al. 1971). There was confusion surrounding the project from the start.

Construction did not follow the structural engineer's specifications for shoring or formwork. Before removal of shores and forms, the concrete must first reach $70 \%$ of its designated 28 day strength in order to meet that specification. It was the commission's opinion that, despite 7 day cylinder tests that said otherwise, the average strength of the concrete in the roof slab was only $13 \mathrm{MPa}(1,900 \mathrm{psi})$ after at least 47 days, not the required 14.5 $\mathrm{MPa}(2,100 \mathrm{psi})$ for removal or the specified $20 \mathrm{MPa}(3,000$ psi) required after 28 days. The reason for disregarding the tests was the difference between the curing conditions in the laboratory and at the project - the concrete on site would gain strength more slowly in cold weather conditions, while laboratory specimens are cured at a specified temperature and humidity. There was no inspection or cylinder testing performed for the east side of the building, so removal of formwork was based on values obtained from the west side of the building. Furthermore, there was no shoring under the roof slab below the freshly placed mechanical room floor slab (Granger et al. 1971).

Finally, there was very little construction control on the site. There was no architectural or engineering inspection of the project, and the inspection done by the City of Boston was inad- 
equate. The design plans specifically stated that certain aspects of the project needed to be approved by an architect, yet no architect or engineer was consulted. Instead, construction was based on arrangements made by the subcontractors. As mentioned before, there was only one representative from the general contractor, and this man was not a licensed builder. He did not direct, supervise, or inspect any of the work done by the subcontractors (Granger et al. 1971).

\section{Similar Cases}

The progressive collapse of 2000 Commonwealth Avenue was similar to the later structural failures of buildings at Bailey's Crossroads and Harbour Cay. On March 2, 1973, the Skyline Plaza in Bailey's Crossroads, Virginia, collapsed while under construction. Like 2000 Commonwealth Avenue, premature removal of shoring and insufficient concrete strength were suggested as the causes of failure. Low temperatures led to an estimated concrete compressive strength of only 6.6-9.9 MPa (960-1,440 psi) at the time of the collapse. A National Bureau of Standards (NBS, now National Institute of Standards and Technology, NIST) investigation team determined that punching shear failure at the twenty-third floor caused a partial collapse that propagated to the ground. Fourteen workers were killed and 34 were injured (Carino et al. 1983).

The collapse of the flat-plate Harbour Cay condominium building in Cocoa Beach, Florida, on March 27, 1981, was caused by a punching shear failure that triggered a progressive collapse, much like 2000 Commonwealth Avenue and Skyline Plaza. Eleven workers were killed and 23 were injured. An NBS investigation team that included two individuals who had investigated the Skyline Plaza collapse determined that the slab thickness of $203 \mathrm{~mm}$ (8 in.) did not meet the ACI code minimum of $279 \mathrm{~mm}$ (11 in.). Also, the top reinforcing steel was placed too low, reducing $d$ from $160 \mathrm{~mm}$ (6.3 in.) to $135 \mathrm{~mm}$ (5.3 in.). As a result, the calculated punching shear stresses exceeded capacity (Lew et al. 1982).

Investigations following the three collapses concluded that both design and construction errors contributed to the cause of collapse. All three failures could have been avoided if better inspections of materials and construction details were conducted. The papers by Lew et al. (1982) and Carino et al. (1983) and other related documents were compiled by the American Concrete Institute for a seminar in Avoiding Failures in Concrete Construction (ACI 1989). In fact, a punching shear failure in Indianapolis was reported as early as 1911 (Feld 1978).

\section{Lessons from This Case}

The Bailey's Crossroads and Harbour Cay collapses resulted in 25 deaths and 58 injuries combined (Lew et al. 1982; Carino et al. 1983). These could have been avoided if the engineers working in Virginia and Florida had learned the lessons of the 2000 Commonwealth Avenue collapse.

This case also illustrates the need for proper shoring of concrete construction. Many failures over the years have occurred due to insufficient shoring or premature removal of shoring and formwork.

Some of the causes of the failure and contributing factors are summarized as follows:

- The owner did not provide competent involvement of design professionals with knowledge of design and construction requirements.
- The contractor did not reshore the slab that failed.

- Concrete, possibly of poor quality, was not adequately protected against cold weather.

- Low top bars in the slab led to inadequate slab depth.

- Construction loads on the roof slab were too high.

- There was no inspection by an architect or engineer, only poor inspections by the City of Boston building inspector, and no inspection by the general contractor's representative (who was not a licensed builder). The owner did not provide quality control of the structural work, and the contractor did not comply with structural specifications.

\section{Conclusions}

Many lessons can be learned from the collapse of 2000 Commonwealth Avenue. The mayor's investigating commission made recommendations for improving the City of Boston's Building Codes. However, the commission also reported that, if the construction of 2000 Commonwealth Avenue had fully complied with existing codes, then the collapse would not have occurred. The commission was dismayed that the project could have progressed through so many phases without the errors and omissions being found and corrected.

The commission made recommendations to prevent similar collapses in the future. These included changes in assigning responsibility and ensuring competence of design, construction, and inspection of major buildings, as well as additions to organization and staff competence of the Building Department. At the time of the failure, the Building Department had 130 employees but only two registered professional engineers, and no registered architect.

In addition, changes in building codes to prevent propagation of a local failure into a general collapse were recommended. In order to facilitate these changes, the commission recommended that the technical findings of the report be made generally available. In the opinion of the writers, this has not been achievedthe Commission's report is not available for loan and must be photocopied at the Boston Public Library.

Finally, this case and the cases of Bailey's Crossroads and Harbour Cay Condominium illustrate the importance and progressive nature of punching shear failure. This is a critical failure mechanism for concrete structures of this type. Structural safety depends on adequate slab thickness, proper placement of reinforcement, and adequate concrete strength.

\section{Acknowledgments}

Funding for this research was made possible by the National Science Foundation's support of the Summer Research Experience for Undergraduates at the University of Alabama at Birmingham, through grant number EEC-9820484. A very special thanks to the first writer's father who spent many hours in the Boston Public Library copying every page of the first volume of the Commission's Report. The second writer is grateful to Henry G. Irwig and James M. Becker, faculty at the Massachusetts Institute of Technology, who first introduced him to this case. The comments and suggestions provided by the anonymous paper reviewers are also gratefully acknowledged.

\section{Notation}

The following symbols are used in this paper:

$b_{0}=$ perimeter of failure surface around column measured at distance $d$ from face; 
$d=$ depth of slab (measured from top or bottom of slab to reinforcing steel location for positive and negative moment, respectively);

$f_{c}^{\prime}=28$-day cylinder compressive strength of concrete; and

$V_{c}=$ punching shear capacity of slab, units of force.

\section{References}

American Concrete Institute (ACI) Committee 318. (1963). "Building code requirements for reinforced concrete." ACI 318-63, Detroit.

American Concrete Institute (ACI). (1989). Avoiding failures in concrete construction, Detroit.

Blake, A. F. (1971). "16-story building falls in Brighton." The Boston Globe, Jan. 26.

Carino, N. J., Woodward, K. A., Leyendecker, E. V., and Fattal, S. G. (1983). "A review of the Skyline Plaza collapse." Concr. Int., July.
"Cause of fatal collapse unknown." (1971). Engineering News Record, Feb. 4,13.

Feld, J. (1978). "Shear failures in concrete frames and slabs." Failure lessons in concrete construction, Harley-Wood, Addison, Ill.

Feld, J., and Carper, K. (1997). Construction failure, 2nd Ed., Wiley, New York.

Ghosh, S. K., Fanella, D. A., and Rabbat, B. G. (1995). Notes on ACI 318-95 building code requirements for structural concrete with design applications, Portland Cement Association, Skokie, Ill.

Granger, R. O., Peirce, J. W., Protze, H. G., Tobin, J. J., and Lally, F. J. (1971). "The building collapse at 2000 Commonwealth Avenue, Boston, Massachusetts, on January 25, 1971." Rep. of the Mayor's Investigating Commission, Mayor's Investigating Commission, of Boston.

Kaminetzky, D. (1991). Design and construction failures: Lessons from forensic investigations, McGraw-Hill, New York.

Lew, H. S., Carino, N. J., and Fattal, S. G. (1982). "Cause of the condominium collapse in Cocoa Beach, Florida." Concr. Int., August.

Litle, W. A. (1972). "Boston collapse." Structural failures: Modes, causes, and responsibilities, ASCE, New York. 